\title{
IMAN-cipation - Identity Politics of young Muslim Women within the "Muslim Youth in Germany e.V. (MJD)" between Agency, Submission and Repression. An Analysis of the Transformation of Gender-Roles
}

\author{
Verena Maske
}

This contribution aims to analyze identity-constructions of young Muslim women who are members of the association of "Muslim Youth in Germany (MJD)". An intersectional approach will highlight the diverse aspects at stake when discussing Islamic identity politics. My data is based on perennial fieldwork within the association of Muslim Youth in Germany e.V. I analyzed both collectively imparted identity constructions, as well as individual perspectives and adoptions in their intersections to give insights into processes of transformation of contemporary Islam correlated to the mediated gender order. Previous studies have pointed out the changing religiosity of young Muslims in Germany as a process of Individualization, which is admittedly considered to be a main factor of religious transformation in contemporary Islam. But my observation revealed that Individualization is rebound to and limited by processes of communitization, which decisively affect issues of gender order and gender roles. Bodies and identities of women thus become the venue of struggles for interpretational sovereignty between Islamophobia on the one hand and apologetic counter-discourses claiming an essential, true Islam on the other.

Gender and religion, Islamic identity politics, Islamic youth culture, women and Islam, Islam and modernity

Verena Maske M.A. is a Ph.D. candidate in the Study of Religions, Philipps-Universität Marburg and research assistant within the DFG-funded project "Islamisch - hip - integriert. Zur Funktion religiöser Vergemeinschaftung für die Identitätsbildung junger Musliminnen der Muslimischen Jugend in Deutschland e.V. (MJD)". Her main interests are contemporary religious culture, especially Islamic youth cultures, Theory and Methodology in the Study of Religions and Religion and Gender.

\section{Introduction}

Young Muslim women in Germany have gained an increasing amount of public visibility within the last few years, since Islam became an important factor within sociopolitical discourses on integration as well as in terms of world politics. ${ }^{1}$

1 Jonker / Amiraux 2006; Lüddeckens / Uehlinger / Walthert 2013; Rabasa 2004. 
Likewise the issues of gender politics and the role of Muslim women have turned into a means of Muslim identity politics, asserted both within inner-Islamic discourses and within wider society. ${ }^{2}$ Discussing the role of Islam in contemporary society and its compability with Western values and lifestyles is often associated with issues of gender and sexuality, which are recognized as important indicators of modernization. ${ }^{3}$ Therefore gender politics serve as a means of constructing cultural and social belonging as well as the construction of distinctions, devaluations and exclusions. ${ }^{4}$ Claims about true Islam and about which Islam should be promoted by Western politics are inextricably linked with negotiating gender roles and gender orders, particularly concerning the role and status of women. Thus, Muslim women are confronted with contradictory social identity ascriptions and expectations, which force them to habitualize a specific social positioning alongside social categories of difference, such as religious affiliation, national belonging, social and educational background as well as age.

This contribution aims to analyze collectively mediated identity-patterns of young Muslim women, who are associated with the group "Muslimische Jugend in Deutschland e.V." (MJD). An intersectional approach will highlight the diverse aspects at stake when discussing Islamic identity politics. ${ }^{5}$ My data is based on fieldwork within the association of Muslimische Jugend in Deutschland e.V., which I conducted from 2007 to 2014. I did an openly and unstructured participant observation at weekly proceeded local activities of young Muslim women associated with the organization in Hannover and at regional and nationwide meetings, which the MJD regularly organizes. ${ }^{6}$ In the beginning I got access to a local girls group associated with the MJD in Hannover, meeting every Sunday afternoon to acquire Islamic knowledge and build an Islamic community spending their leisure time together. While attending this weekly meetings I noticed that community buildung is crucial for those young Muslim women. A strong and firm "Ummah" and capturing true Islam, rather than individualization are central issues to the propagated understanding of Islam. Therefoe, I focused my research on the organization and the surrounding youth scene, analyzing collective identity patterns, the mediated understanding of Islam and processes of community buildung and identity politics. I attended several germanwide meetings organized as big youth-cultural events lasting several days, regional meetings, the members meeting and a summer school organized for dedicated members. I talked to particpants as well as members of the MJD, attended Islamic lectures, and visited the bazaar, concerts of Nasheed-musicians and Islamic comedy performances to capture both collectively imparted identity constructions as well as individual

2 Spielhaus 2011; Tiesler 2006.

3 Von Braun / Mathes 2007; van der Loom / van Reijen 1992.

4 Jenkins 2008.

5 Degele / Winker 2009; Crenshaw 1991, S. 1241-1299.

6 Franke / Maske 2011, S. 105-134. 
perspectives and adoptions. I also interviewed two (male) chairmen of the association to gather Data about the association, its history, its structure of organization and its purposes and activities as well as seven young Muslim women who are actively associated with the MJD with guided interviews to ascertain the meaning and importance of the Islamic concept of the Ummah, the belonging to the MJD and the surrounding youth culture scene as well as the orientation towards Islamic role models. Furthermore, I analyzed data from the surrounding Muslim youth culture represented within the MJD-events to capture expressions of the sense of life and the propagation of the Islamic worldview and lifestyle. Due to my interest in collective patterns of identity-constructions I analyzed the data not case-related, but on-topic inductively and deductively by a qualitative content analysis to give insights in processes of transformation of contemporary Islam correlated to the mediated gender order. ${ }^{7}$

Gender in this regard is understood as a social construct, which should be analyzed in its emergence, reproduction and transformation as an instrument of social power relations. Taking a gender-critical approach implies not just analyzing the status, roles and ideal images of women, but furthermore the whole gender order, its notion of normality and taken-for-grantedness as well as its devaluations, exclusions and social boundaries. ${ }^{8}$ In light of my position as a female researcher, there were limits to my grasp of all aspects of the established gender order, but to the extent deemed possible, I analyzed the gender constructions within the field in general. Nevertheless, I focus on Muslim women not just due to my access to the field, but because most members of the MJD are female, confidently critizising patriarchal structures of traditional Islam and demanding changes in the direction of women's emancipation, but also devout and firmly practicing Islam in a rather social conservative understanding as a central part of their everyday life. The overrepresentation of women correlates to the ascribed importance of Muslim women within contemporary inner-Islamic discourses as well as within society. ${ }^{9}$

The gendered Islamic identity politics go along with forces of compliance, peer pressure and submission, but also provide individual agency, empowerment and representation as the young Muslim women I got to know explicitly decided to adopt these Islamic identity patterns and the propagated Islamic lifestyle with its opportunities as well as duties and limitations. This paper reflects the antagonostic tension between processes of religious individualization and communitization, both playing a part in contemporary transformations of gender and religion within Islamic youth culture. I will analyze the intersections of individual and collective identity constructions mediated by the MJD. This aims to exemplarily close the gap between studies focussing on the individual level of religiosity, religious

7 Ebd.

8 Franke / Maske 2012, S. 125-140.

9 Bano / Kalmbach (eds.) 2012; Meining 2011, S. 147-153. 
lifestyles and identity constructions on the one hand and studies examining Muslim organizations and the collective identity politics they deal with in religious and social discourses on the other. In this way I analyze the identity constructions of young Muslim women as subjects actively doing gender and doing religion and at the same time as objects, which are embedded in collectively constructed social realities, since they have to adopt world views, habits and selfconceptions to identify with. This perspective correlating micro- and mesolevel is considered to be an important challenge for the Study of Religions as well as for Gender Studies. ${ }^{10}$

The observation that "community" and the "Muslim Ummah" are central issues both for affiliated young Muslim women as well as for the understanding of Islam the MJD mediates was the starting point of this focus. ${ }^{11}$ The importance ascribed to the construct of the Ummah within the field emphasizes that the aspect of communitization and the relevance of social constellations of the wider context in general, as well as of Islamic traditions in particular, are currently overlooked within research. It has to be asked within a gendercritical perspective what belonging to the Ummah in the shape of identifying with the MJD and the surrounding Muslim youth culture means for young Muslim women, how community is constructed and what social consequences the Islamic gender identities demanded by the organization are implying. Processes of identification and belonging on the one hand as well as of distinction and ethnocentric processes of othering on the other must be analyzed as means of negotiating agency, while all at once limiting options of social action. Collectively mediated identity politics expressed and conveyed by religion, by issues of gender and sexuality and by youthculture in their interrelationship are described and critically analyzed within the scope of current power relations.

The premise of my remark is that community within the MJD is produced by means of propagating an Islamic authorized gender order and by establishing an Islamic youth culture. Both the specific gender order and the Islamic youth culture function as materialized symbols and social representations of the propagated Islamic worldview, which claims interpetational sovereignty. Gender and youth culture thus become central means and indicators of adopting a "correct" understanding of Islam and provide identification and distinction, belonging and exclusion towards everything identified as un-Islamic all at once. This however changes contextually, depending on situational positioning towards different social groups.

Issues of Islamic gender roles figure prominently within the MJD, as gender politics denote a social and religious positioning towards Islamic traditions as well as towards Western Feminism. Given contradictory and even conflicting identity ascriptions, that have to be brought in tune with individual interests and needs,

10 Degele / Winker 2009, S. 18-24.

11 Cf. internet sources: "Wir gewinnt!"; Ummah 2.0. 
young Muslim women search for orientiation and role-models to identify with: Can Muslim women also be emancipated? How does Islam adhere to Western Feminsm? Is there an Islamic way to treat the opposite sex, to win a partner, to deal with sexuality? Such questions are omnipresent in face-to-face conversations, lectures, Islamic materials and books, in Nasheed-songs and other artefacts of Islamic popular youth-culture encountered in the setting of the MJD. The centrality of these questions results in the specific development tasks of youths to adopt a gender role and a sexual identity, to accept bodily changes and to build relationships. ${ }^{12}$ Moreover, the importance of this issue originates from divergent, gendered value orders that young Muslim women are confronted with: the parents and their traditional Islamic suggestions and prescriptions, the peers with their leisure-oriented hedonism and German society, represented mainly by the educational system and media, which is predominantly perceived as discriminatory, stigmatizing and excluding, but demanding active integration. These contexts are perceived as contradictory life worlds that have to be brought in tune. ${ }^{13}$ The current gender order is perceived as fragile and contested due to processes of social change and individualization. ${ }^{14}$ This provides opportunities of liberation from gender roles and sexual norms, but also causes insecurity and disorientation, which applies especially to young Muslim women. ${ }^{15}$ They ask themeselves why they aren't conceded the same degrees of freedom as their nonmuslim peers, if being a Muslim woman means the resignment of fun, if Islamic prescriptions contain a deeper sense and if indivdual needs can be harmonized with expectations of parents and Islamic rules.

To transform contradictory identity ascriptions and individual needs into a specific social positioning, young Muslim women draw on inner-Islamic discourses, arguments and suggested identity politics ranging from the criticism of Islamic tradition to social criticism of Western modernity by referring to the concept of true Islam, which among other Islamic groups is mediated within the MJD. ${ }^{16}$ The MJD propagates distinctly Islamic and gendered idenity-politics, which oppose individual inner conflicts and fragmentation by presenting Islam as the center of ones life, as an orientational framework regarding all spheres of life.

First, I will give a brief introduction to the MJD within the context of Islamic youth cultures, then I will analyze the concept of an ideal Muslim woman mediated by the MJD within the context of an Islamic gender-order as specific identity politics, which is adopted and habitualized by its female members to acquire Allah's delight and to construct belonging to the Ummah as a community of true believers. A theoretical conclusion will highlight the transformations of gender-

12 Fend 2003; Hurrelmann 2007; Havighurst 1953.

13 Von Wensierski 2007; Breuer 2006; Hunner-Kreisel / Andresen (eds.): 2010.

14 Beck/ Beck-Gernsheim 1998.

15 Whitehead / Talahite / Moodley 2013, VIII ff.

16 Nökel 2002. 
roles and Islam as interdepedent factors of social change, which are analyzed critically.

\section{The Muslim Youth in Germany - a brief introduction}

The Muslimische Jugend in Deutschland e.V. (MJD) is the first independently youth-lead Islamic organization in Germany, founded in 1994. Members are between thirteen and thirty years of age, and so the leadership ranks are occupied by young Muslim men and women, who challenge traditional understandings of Islam, which are commonly combined with national customs. It is one of the first organizations claiming to propagate a German Islam, considering it necessary to regard Germany as home and therefore demanding opportunities to participate as Muslims in German society. Hence the Lingua Franca within the organization is German. A further reason for this is that membership is independent of national descent, which is quite extraordinary in Germany. ${ }^{17}$ Members of the MJD are young men and women from Egypt, Morocco, Turkey, Syria, Uzbekistan, Afghanistan, Iraq among others, dominated by participants of Arab or bi-national descent, mostly rather well-educated. Due to the organisation's understanding of itself as open to the plurality of Islamic traditions, there are also some Shiites among the members. This universal and inclusive approach rejects the blending of nationalism and Islam as well as traditional understandings. But the adherence to Islamic internationalism certainly does not imply tolerance towards other Islamic traditions as it propagates one true Islam implying distinct limits. ${ }^{18}$

As an Islamic youth organization, the MJD claims representation and interpretational sovereignty over all young Muslims in Germany as is already visible in its self-designation: the Muslim Youth in Germany. Such a claim cannot be justified since there are an estimated 800 to 900 members - even if the group actually is the second largest Muslim youth organization in Germany. Whilst being rather small, the MJD gains a lot of public visibility, being involved in interreligious dialogue and in structures of socio-political discourse. ${ }^{19}$

Financially and structurally independent, the MJD derives from an Islamic scene of converts and Muslim intellectuals of Arabic origin. It is supposed to be affiliated with the Islamische Gemeinschaft Deutschland eV., which is held to be the german branch of the Muslim Brotherhood ${ }^{20}$, and which had already emerged before the migration of the German Gastarbeiter after the Second World War. ${ }^{21}$

17 Al-Harmaneh, / Thielmann (eds.) 2008.

18 Cf. Internet sources: Muslimischen Jugend in Deutschland e. V. (MJD) website; Bendixen 2013, pp. 32-46.

19 Maske 2010a; Cavuldak 2011.

20 Maréchal 2008; Mitchell 1993.

21 Meining 2011, pp. $223 \mathrm{ff}$. 
The MJD is involved in a transnational network of Islamic youth organizations in Europe consolidated by the World Assembly of Muslim Youth (WAMY) based in Riad. ${ }^{22}$ Therefore it does not represent Islamic plurality, as it claims, but a transnational Islamic movement propagating a specific understanding of Islam. Analyzing the contents and messages of the courses and meetings and looking at the persons perceived as authorities and at the organizations the Muslim youth cooperates with on national and international levels proves that the organization rather stands for a specific Islamic orientation that produces exclusions by propagating one true Islam. Whilst trying to unite Islamic traditions and movements making a reference to the as-salaf-as-salih (the pious ancestors), they consider Islam to be an unchangeable and universal guideline providing disagreements, but only within clearcut, god-given limits - as comparable to a soccer field, as a member once explained to me. Innovations which are not based on Islamic principals as provided by Quran und Sunna are considered to be haram. ${ }^{23}$ Blaming other understandings of Islam as innovations (Bi'da) provides a positioning within inner-Islamic discourses.

Because of personal and substantial connections to the Muslim Brotherhood, the Federal Office for the Protection of the Constitution observed the Organization as an Islamistic hazard and referred to them in several reports. ${ }^{24}$ The MJD denies these accusations and tries to redeem itself; therefore it is actively involved in religious and sociopolitical dialogue and political authorities cooperate with it. Thus it also stands for the process of increasing visibility in German public and for processes of institutionalization, differentiation and pluralization of Islamic landscape along target-group-specific interests.

The MJD understands itself not just as a sociopolitical advocacy of Muslim youth in Germany, and as part of the Muslim Ummah, it is also a platform for, and a starting point of, Muslim youth culture, which is supposed to offer Islamic education and lifestyle opportunities. In this regard Islamic pop culture is seen as an important means of Da'wa (invitation to Islam), as an expression of re-actualising Islam in the given context as a vivid tradition. ${ }^{25}$ Julia Gerlach labeled this transnational Islamic youth culture as Pop-Islam. This is not a self-designation, but points to the new mixture of pop culture and a rather conservative Islamic faith, propagating the aspiration after success and participation in society and fighting against Islamophobia by showing how Islam in an idealized true version

22 Cf. Internet sources: FEMYSO; World Assembly of Muslim Youth (WAMY).

23 This refers to Islamist thinkers as Hassan al-Banna, Sayyid Qutb and Sayyid Abul Ala Maudi.

24 Verfassungsschutzberichte des Innenministerium Baden-Würtemberg 2005, 2006, 2007, 2013; Bundesministerium für Inneres 2010; Hessisches Ministerium für Inneres 2010, 2011, Bayerischen Staatsministerium für Inneres 2010-2015; Cf. Internet sources: Dernbach 2015.

25 Maske 2013, pp. 87-107. 
really is. Music, fashion and cultural activities are Islamized, in style as well as in content, to mediate an Islamic message. There are new fashion labels such as StyleIslam $^{26}$, which combines Islamic dress-regulations with Western fashion styles and pursues Islamic identity politics. There is also a new music genre with its own stars, labels and media-channels: Nasheeds in pop- and hip hop-style with international stars like Sami Yusuf, Maher Zain, Yusuf Islam, Native Deen, The Sound of Reason and many more. ${ }^{27}$

As a result of processes of individualization and secularization Muslims belonging to the MJD believe that one is not Muslim by birth, but instead has to make a conscious decision that feeds into all areas of life. ${ }^{28}$ Islam is believed to be an ideal system, since nothing is supposed to be forbidden that is good, and nothing is allowed that harms anyone or anything. So Islamic prescriptions make unquestionable sense and have to be obeyed by individuals and ideally as well by larger society, even if one does not apprehend it. This central message is delivered in various meetings, courses and events, which are supposed to help young people find their way to practice Islam in a strict sense, but likewise fitted to the modern way of life. Within the MJD young people teach and urge themselves to live according to Islamic rules, and they use pop culture to distribute their message - at low-threshold weekly meetings, at constructive courses, which can only be attended via invitation and claiming high devotedness and at huge youth camps with performances of Islamic musicians, comedians and different leisure activities, building up an ideal Islamic society for a few days. This is believed to delight and inspire young Muslims to transport this lifestyle into their everyday-life.

The MJD as part of the pop-Islamic youth scene is embedded within a wider field of secular and Islamic youth cultures. Adolescents with a Muslim background in Germany identify outstandingly with being a Muslim due to social ascriptions especially after $9 / 11$, but this identification is related to rather different styles of religiosity: Some consider their Islamic identity just as part of being discriminated against as foreigners and outlaws, others due to their socio-cultural background or as one more or less important sphere of life amongst others. And, like young Muslims associated with the MJD, some are explicitly religious and consider Islam a very important or even central part of their lives. ${ }^{29}$ Islamic youth cultures and organizations such as the MJD do not appertain to this in huge numbers, but are a publicly visible and active religious group. They are situated within the established traditional Islamic organizations, which offer Islamic education and youth-work ${ }^{30}$ and the growing Salafist movement, which especially

\footnotetext{
26 Cf. Internet sources: Styleislam.

27 Gerlach, Julia. 2013; Herding 2013.

28 Roy 2006; Klinkhammer 2000.

29 Lübcke / von Wensierski (eds.). 2007; Cf. Internet sources: Dantschke 2007; Kiefer 2009.
}

30 Lemmen 2000. 
attracts young people and due to its literal understanding of Islamic sources and its sometimes violent manifestations currently causes a lot of public debates. ${ }^{31}$ The MJD situates itself within this field by propagating a specific understanding of true Islam, which is also negotiated by mediating gender roles. Taking this into account, the young Muslim women associated with the MJD are agents of specific Islamic identity politics not only towards German society, but also towards other Muslims and Islamic groups.

\section{Self-concepts and feminine role models mediated by the MJD}

The young women I met in the course of my research process understand themselves to be emancipated and therefore misunderstood by Western feminists and excluded by Islamophobic social discourses, all at once striving for the liberation of traditional Islamic patriarchy. Some have obtained an intense religious education, others hardly any. Mostly in the light of the events after 9/11 and because of ascription of being a Muslim in school they felt challenged to take their own position towards contradictory ascriptions: Is Islam really such a terrible religion, full of prohibitions and terror? And what does it mean to be a Muslim woman here and now? Keen to acquire Islamic knowledge regarding these questions, they look for their own spaces of discussion to be independent of the views and expectations of their parents as well as of society, and at the same time seeking assurance and guidance from Islamic scholars and trustworthy role models - in private girl groups, youth groups and youth cultures and thus within the MJD.

For some, the MJD is a central, family-like part of their life, others consider the organization and their offered activities part of a larger Islamic movement they attend occasionally. The locally situated, weekly meetings of the girl group belonging to the MJD is mostly appreciated as a place where they can talk about their everyday problems without feeling pressure to justify their Islamic socialization, which is rather taken for granted as a common background. The gender separation established by the MJD, dividing members into groups of brothers and sisters at the local level, is considered to be a factor of empowerment, as this provides protected spaces to talk freely about what moves them, especially regarding issues of partnership, marriage and sexuality. Huge meetings attended by both sexes enable them as hip events to get in contact with young devout Muslims observing Islamic prescriptions and overall to experience and create individual expressions of religiosity according to their sense of life, but at once not feeling like an outsider, but instead as an important part of a larger movement.

In their daily lives the young Muslim women affiliated with the MJD experience their turn to Islam as stabilizing their identity, as a way to establish a likeminded, encouraging community while expanding their scope of action, which is,

31 Schneiders, Thorsten Gerald. 2014; Ceylan / Kiefer (eds.). 201; Mansour 2015. 
in some cases, rather meant literally: some young women attending the meetings are not allowed to leave the parental home apart from going to school or to vocational areas, the mosque or to meet their girl friends. Thus some are not permitted to attend youth cultural spaces due to their perceived hedonism, especially the mixing of the sexes, and the use of alcohol and drugs. The MJD offers young Muslim women a unique opportunity to gain a recreational space, which is not controlled by parents or adults. Here they are able to express their juvenile sense of life and world view combined with a rather conservative understanding of Islam, claiming the freedom to decide against those aspects of liberation which in this view are not compatible with Islamic rules. In the light of predominantly traditional, authorative and patriarchal family structures the understandings of Islam and gender as represented by the MJD are experienced as liberating, but likewise accepted also by parents threatening their daughters especially with massive penalties for breach of trust. Many discussions in the girl group centered on the feeling of being misunderstood and treated extremely unfair, since the MJD has to fight against the accusation of being too conservative or even Islamist coming from German society and all at once has to resist allegations by parents and other Islamic organizations, of mediating a too lax interpretation of Islamic precepts. So the gendered identity politics the MJD offers can be described as a creative bricolage regarding pluralized references of belonging by processes of identification and distinction all at once..$^{32}$ The individual appropriation of a religious and gender identity are deeply intertwined with constructions of collective belonging on the one side and processes of social exclusion on the other, since individual identities are reliant on social recognition and therefore embedded in social power relations. ${ }^{33} \mathrm{~A}$ migrant background offers pluralized references of belonging, but affiliations are also often questioned or even denied, with the result that issues of belonging are omnipresent ${ }^{34}$ and become a process of their own dynamics. Ascriptions commonly turn into transformed, revalued self-conceptions, not just on an individual level, but also as a matter of collective discourse. ${ }^{35}$ The identity politics the MJD and the surrounding youth culture propagate are driven by a specific understanding of Islam which is deeply adjuncted to a mediated gender order, and especially shaped by a specific female role model, which I will highlight in the following.

Given the fact that criticism of Islam is often coupled with critizising the role of women and their veiling, which is considered to be a symbol of opression and misogyny, it is not only an individual need for these Muslim women to distinguish themselves from attributions by society or the traditional parental generation. It also is an inner-Islamic discourse strategy of scholars and authorities to offer

32 Maske 2010c.

33 Jenkins 2008; Honneth 1998.

34 Riegel / Geisen 2007.

35 Goffman 2014 [1963]. 
subsequent collective identity patterns. Muslim women themeselves claim representation and become part of a discourse on clothing and Islamic lifestyle and infrastructure, which is considered as Da'wa (invitation to Islam) and is not only a private or individual issue, but also a political one. ${ }^{36}$ As such, it is embedded within a movement of ideological support from Islamic countries, which was established since the 1980s. ${ }^{37}$ It claims for recognition of Islamic identity being a constitutive part of society ${ }^{38}$ by insisting on minority rights. ${ }^{39}$ Due to strict gender segregation and rigid sexual morals, gender plays an important role as a category of difference within the MJD, coupled with claims of moral superiority towards Western hedonism, liberalism and secularism and also as evidence of obeying true Islam towards other Islamic traditions and movements.

An event poster for the annual Muslim girls meeting 2010 illustrates the role model of an ideal Muslim woman that is explicitly mediated in lectures, teaching materials and creative contributions of the MJD. ${ }^{40}$ Four images show the ideal Muslim woman in comic style with colourful backgrounds as 1) actively fighting, 2) reading, 3) working at a laptop and 4) dandling a baby in her arm. I think these pictures stand for four characteristics defining an ideal Muslim woman:

1. Brave, combative, confident, action-oriented, energetic and committed

2. Educated, eager for knowledge and disciplined

3. Employed and successfully building their career

4. Finally, maternal, as a married wife and a good mother

The images suggest that a perfect Muslim woman is wearing a headscarf, adhering to Islamic prescriptions of modesty combined with a modern fashion style. Within the MJD veiling is presented as a religious duty women should proudly obey as a sign of their true belief and their belonging to the Muslim Ummah. It is accepted if a Muslim woman decides against wearing a headscarf, but it is presented as an individual maturing process to prospectively wear it. The submission under the will of Allah according to prescriptions of Quran and Sunna is - according to the interpretation of Islam the MJD mediates - uncompromisingly expected within all spheres of everyday life. ${ }^{41}$

36 Giddens 1991; Nökel 2002, p. 18.

37 Haddad / Smith (eds. .) 2002, pp. v-xviii.

38 Kepel 1996, p. 342.

39 Barot 1993; Barth 1969; Vertovec / Peach (eds.). 1997.

40 The MJD advertises its events via such posters referring to pop-cultural styles, likewise mediating its understanding of Islam. This poster promoted the annual meeting of muslim girls in 2010, with the slogan "Muslimas mit MUMM". It contains a pun becaue MUMM is the shortcut of Muslim Girls Meeting, but also means energy, courage, expertise. Cf. Internet sources: Muslimas mit Mumm!.

41 Demiryürek 2007, p. 2. 
The presented concept of female identity re-evaluates different attributions and expectations of German society as well as of the parental generation with recourse to Islam to finally develop one's own positioning. ${ }^{42}$ Young Muslim women affiliated with the MJD are acquiring this genderd Islamic role model to obtain social recognition. They are also encouraged by young Muslim women in leading positions within the MJD, since they consider them as role models and as a proof that a Muslim woman is also able to be successful and emancipated.

In the following I will describe the characteristics of an ideal Muslim woman referring specifically to the identity politics mediated by the MJD propagating a bricolage challenging the dualistic view of traditional and modern.

\section{Challenging traditional Islamic gender-roles. Education, career and social participation as a means to strive for emancipation}

Referring to the interpretation of Iqra (read) $)^{43}$ as a general call for education, young Muslim women within the MJD are encouraged to pursue higher educational qualification. As a result of exposure to the MJD, many of the educational careers of its members have undergone a positive change. School, university and professional development as well as successes are accompanied, supported and celebrated within the organization. Striving for education and success is regarded as a service to Allah, as fulfilling a god-given duty and as an inidicator of being elected by him. ${ }^{44}$

The young Muslim women justify their educational aspirations with reference to the wives of the prophet, which are seen as role models in every respect. Thus a manual of the Muslim Youth illustrates, for example, that Khadijah was a very successful business woman of high rank and gifted with excellent intelligence and that Aisha not only fought on the side of her husband on the battlefield, but also was an encompassingly educated woman who has delivered most descended hadiths. ${ }^{45}$ With reference to them, the young women justify their extended educational period and the delay of marriage as well as the associated space to seek a professional activity that grants them independence and recognition and thus are tolerated and respected by their parents.

Since it is perceived as the most important aim in life to attain Allah's delight, an occupation is only regarded as desirable when it does not preclude this intent,

42 Schiffauer 2002; Klinkhammer 2000; Nökel 2002.

43 According to tradition this is the first revealed word Allah commands via the angel Gabriel to Muhammad, cf. Sura 96.

44 Weber 2016 (orig. 1905); Nökel 2002.

45 The Manual is not available anymore. It is based on a shortened and modified translation of Amr Khaleds Series "The mothers of believers." 
or, ideally, even serves it. Due to this premise, a majority of Muslim women associated with the MJD are studying medicine, law or education, which are seen as vocations serving society in a feminine way. Jobs at bars or supermarkets to finance studying, where you have to sell alcohol and cigarettes, are regarded as unIslamic (haram) and are therefore considered as forbidden. Moreover, they hope to get a job where they are allowed to wear headscarves. Removing the headscarf is regarded as unacceptable for most of them. Rather, they are convinced to fight and stand firm for their right of living according to Islamic prescriptions, as the teacher Fereshta Ludin, once a leading member of the MJD, did a few years ago (1998-2003), when she was the cause of the German headscarf debate. ${ }^{46}$

The MJD also recommends volunteer activities, such as a religious duty, especially to young Muslim women. Thus they engage with great dedication and discipline in various local Islamic groups and initiatives and also in charitable activities. A few of the Muslim women eventually combine their religious beliefs with professional and sociopolitical commitment. They start a publishing company for Islamic novels ${ }^{47}$ work at Islamic development aid agencies ${ }^{48}$ in Islamic media, within Islamic fashion labels, ${ }^{49}$ Islamic organizations or an Islamic environmental organization. ${ }^{50}$

As women who are sophisticated and successful in their career, they explicitly and vehemently oppose the widespread image of Muslim women as being disenfranchised, illeterate and fanatical; rather, they make themselves out to be selfdetermined and socially involved cosmopolitans who claim their right to make Islam viable in a modern world. Thus they reject traditional Islamic female role models as ultimately un-Islamic and connect Islamic and modern female role concepts by re-interpreting the sources as they claim to be indepedent, selfdetermined, striving for education and pursuing a career, but also being serious, pious women. They also oppose a literalist Salafi understanding of the role of women. But this is not evidence of being liberal at all - since they oppose an interpretation of Islamic sources on the basis of critical hermeneutics, for this is seen as an adjustment of Islam to the ideology of modernity and liberalism and therefore as Bi'da (un-Islamic innovation). ${ }^{51}$

46 Meining 2011, pp. 231 ff., Amir-Moazami 2007.

47 Cf. Internet sources: Narrabila-Verlag.

48 Cf. Internet sources: Islamic Relief Deutschland.

49 Cf. Internet sources: Styleislam.

50 Cf. Internet sources: Hima - Natur- und Umweltschutz aus islamischer Perspektive.

51 Demiryürek 2007, pp. 131-143. 
Verena Maske

\section{Iman-zipation. Being a devout, chaste and careful mother and an obedient wife}

However, the Muslim women associated to the MJD also distinguish their selfconcept from the Western feminist model of emancipation, for they see themselves in the role of a devoted, virtuous and chaste wife and mostly prospectively as a mother striving for perfection of their character within the meaning of Islamic law. This is based on the creed that Islam as a perfect system satisfies female needs in an ideal way, while feminism is based on the decadence of the Western world and ultimately leads to sexual exploitation of women, threatening them with ideals of beauty, misleading them to leave the god-given way, driving them directly into hell fire.

The MJD however suggests a strict Islamic gender order: Female emancipation and the devotion to Islam are considered as mutual causal factors, such as in the following title of a lecture at a meeting I attended in 2011: "Iman- zipation Women, Islam and rights"- Iman means confident belief. This is not emancipation as a turning away from Islam, but Iman-zipation, because if women are strengthening their faith and they know more about Islam and how to live it the right way, they automatically reinforce their rights as women. Oppression of women is meant to be un-Islamic, while obeying true and pure Islamic rules per se implies liberation within a god-given and therefore beneficial path. True Islam is extracted by searching for the meaning behind Islamic rules and by using free space, for what is not forbidden explicitly is considered to be permitted. ${ }^{52}$

The starting point of this argumentation is the premise that men and women are created as equal before God, but not identical in their nature, which is why they share complementary tasks in partnership: the man as breadwinner and head of the family, the woman as mother and supportive wife in the first place, and both as servants of Allah. Marriage is seen as a natural duty and basal foundation of society. Reverse of the medal women are granted the greatest possible respect in their role as a mother. These ideas also are expressed by artefacts of Islamic youth culture, for example in poetry slams ${ }^{53}$ as well as in many Islamic songs ${ }^{54}$ and pictures mediated in social media. ${ }^{55}$ This idealization is based on neo-traditional ideas and does mostly not comply with reality as well as with Islamic sources, which consider sexual obedience as the main duty of women (not education or housework). ${ }^{56}$

52 Nökel 2002, pp. 54 ff.

53 Cf. Internet sources: i,Slam: Khalid Bounouar - Mutter.

54 Cf. Internet sources: Sami Yusuf - Mother; My Mum is Amazing - Allah Knows by Zain Bhikha: My mum is amazing; Women I love - Zain Bhikha - Official video 2011; The Sound of Reason - Mom Song.

55 Cf. Internet sources : Nayzak; Zaki.

56 Ali 2006, pp. xii-xxviii. 
Promoting a specific model of an ideal family goes ahead with exclusions and is connected to discard certain models of life as illegitimate according to Islam. Remaining single is considered to be un-Islamic, although some of these women are not married as they are facing problems to find an adequate spouse. Homosexuality and transgender identities are viewed as unnatural phenomena, characterizing a sick society and arising from perverted individual needs. At a regional meeting, a lecture addressed the central importance of wearing the wedding ring; the lecturer explained to the audience that nowadays it must not only protect against sexual harassment from the opposite, but actually also from the same sex, which can be seen as a symptom of a degenerated society. ${ }^{57}$

Most Muslim women told me they wished for a romantic love match with a lifetime partner who supports them in their efforts of emancipation and who they choose themselves - irrespective of his national background, something parents often consider to be an important criteria for a suitable spouse. Forced marriages are considered to be an un-Islamic cultural custom. Hence the MJD supported an action alliance with Tariq Ramadan fighting against this custom. ${ }^{58}$ Discussions on this topic in a local group of the MJD revealed, however, that the realization of this fight is not easy. If the parents cannot be convinced over their children's right to choose a partner, resistance sometimes implies the decision to break off contact with the familiy.

Transformations take place as ideas of romantic partnership are Islamized, but combined with norms of piety and modesty. The Idea of a soulmate especially created for each person is spread across various media, including Islamic pop songs like "For the rest of my life" by Maher Zain. ${ }^{59}$ The music video mediates a new Islamic image of men as a caring husband and father. The extent to which young Muslims identify with it is difficult to estimate. This reveals a research desideratum, not least because Muslim men can indeed limit the claims and selfimages of women. Research has to be amended to analyze the gender order among Muslim youth as a whole.

Young Muslim women associated with the MJD portray the man of their dreams as a devout Muslim, and hence as sophisticated, dedicated, loyal and caring, romantic, intelligent, humorous and professionally successful. All these characteristics are considered to be guaranteed by practizing true Islam, since it contributes to the formation of character, for a devout Muslim is guided by the example of the prophet, who is seen as the most ideal role model, an absolutely perfect husband and father. ${ }^{60}$ This corresponds to the request of the Egyptian

57 Data based on Participant observation.

58 Cf. Internet sources: anonymous3188897430; Orde, Sabine.

59 Cf. Internet sources: Maher Zain - For the rest of my life.

60 Alpsoy 2007, pp. 95, ff, pp. 65 ff; Cf. Internet sources: Rasoulallah.net Versionen:

Der Prophet als Ehemann; Regarding to the hadith at-Timirdhi 11. 
televangelist Amr Khaled ${ }^{61}$, a superstar of the pop-Islamic movement, that the choice of spouses should be based primarily on the criterion of piety. Furthermore he advises: "You girls and boys who commit sins in the name of love. The shame and the error is not love, but the way we live it." ${ }^{.2}$ (Translation V.M.)

The idea of soul-mates thus is related to the restriction of any sexual contacts before and outside of marriage. To avoid forbidden sexual offences, the relationship between the sexes must, according to the MJD, be controlled. An Islamic gender relation in the sense of the MJD is as follows: at the local level, groups are separated into brothers and sisters. At regional and national events young men and women are gathered on the same site, but a clear separation of the sexes is established, as they are commanded to prevent any illegitimate touch. In lecture halls one side is intended for males, the other for the female audience; they do have seperate entrances and counselors as well as security-personnel of the same sex. Eye contact should be denied, participants are compelled to drop their gazes instead. ${ }^{63}$ During the night, fornication is prevented by patrolling security personnel. Girls and boys are not allowed to dance or sing whilst attending performances of Islamic pop and hip-hop stars, they are only allowed to softly clap their hands or sway gently to the rhythm to avoid drawing attention by the opposite sex. Musicians are all males, as women are mainly not allowed to perform as singers before a male audience. Although this advice is controversial, the MJD sticks to it to as many parents are considered to be upset instead. But young women are allowed to give lectures and become members of the Shura, which in traditional understanding of Islam is impossible. A man is never allowed to be alone with a woman, contact between the sexes is only allowed within a group of people. ${ }^{64}$ Banners and booklets convey these rules as well as personal instruction by tutors, who urge the participants to conform their behavior to Islamic rules.

A key element concerning the indispensible separation of the sexes is also the issue of Islamic dress. The participants urge each other to wear appropriate clothes, but the girls are also discussing Islamic fashion trends and beauty tips. Despite the common belief that clothes should not be too revealing, a disagreement exists as to how closely the commandment of covering must be interpreted and to what extent an orientation to Western fashion ideals is legitimate ${ }^{65}$ Such discourses regarding the symbolic meaning of clothing entrenching subtle distinctions are numerous within the MJD, with the majority lead by Islamic rules

61 Gerlach 2006, pp. 34 ff.; Amr Khaled is often referred to in teaching materials the MJD uses.

62 MJD-Manual.

63 According to Sura 24:30-31.

64 "Behold! A man is not alone with a woman but the third of them is Ash-Shaitan" atTirmidhi Nr. 2165.

65 The discourses on proper Islamic clothing also take place in social media by admonitoty pictures, such as this one: Cf. internet sources: This is not hijab. 
while regarding Western fashion ideas to a different extent. The young Muslim women also claim Islamic behavior and dressing for Muslim men, as this is considered to establish gender justice. ${ }^{66}$

I repeatedly observed that some participants percieve the understanding of Islam the MJD promotes as too strict, conservative and old-fashioned; but they withdrew without igniting a debate. Inner-Islamic discourses are instead conducted with even more conservative Salafi groups and individuals. A member of the leading committee of the MJD (Shura) told me apprehensively that young Muslim women increasingly express concerns about whether they really are allowed to travel through Germany all alone without their " $m a$ hram",67 whether the clothes they wear are too trendy and if gigs of Nasheed bands and theater groups in front of a mixed audience are Islamically illegitimate. In contrast to literalist understandings of Islamic sources, the MJD tries to convince their members to practice an Islamic lifestyle while taking into account the realities of their lifeworlds, using all possibilities of interpretation within Islamic limits, for Islam is considered as a helpful advice how to live in a benefiting way rather than being a burden. ${ }^{68}$ In a booklet published by the MJD titled "Young and Muslim in Germany" by Mustafa Demiryürek, various everyday situations and Islamic solutions are presented, including the question: According to Islam, is it allowed to have a girlfriend or a boyfriend?

Many would now like to have a clear yes or no. But we never get behind the logic of why Islam forbids or commands anything. There is this more than interesting verse: And you do not approach the Zina (unlawful sexual relation)! Certainly, it is a shameful deed and disgraceful is that way (17:32). (...) Whoever enters into a situation where all sexual suggestions are given, one can not control oneself, because the appeal of the naked body is too large and the resistance of the person breaks. Therefore, Allah in this verse forbids being close to the opposite sex, because it almost always leads to fornication. (...) The process is often observed as follows: What began with butterflies in the stomach ends with a really big sin. (...) We have to understand that a date outside of marriage has no Baraka (blessing) and often goes along with giving up religion. ${ }^{69}$ (Translation V.M.)

If you fall in love with a non-Muslim or the desired partner is not practicing at all, the recommendation in another book, the youth novel "Noura", is to stay true to one's religious principles, even if this is a sacrifice - after all, the relationship to the creator is considered to be more important than any other connection. ${ }^{70}$

66 Maske, Verena. 2010b, pp. 235-260; Tarlo / Moers (eds.). 2013.

67 Quran 24:31. Denotes a relative a Muslim is not allowed to marry, and who escorts women while travelling.

68 Ramadan 2009.

69 Demiryürek 2007, pp. 40-44.

70 Abed 2011. The author and the publisher are associated with the MJD and the book distributed at Basars detained by MJD-Meetings. 
The young Muslim women struggle to find a spouse who will meet their needs. How to comply with their own desires, the expectations of parents and the Islamic context, is a difficult task for young Muslims. Nevertheless they consider the Islamic frame of matchmaking as good protection for themselves for not being sexually exploited and emotionally hurt.

Arranged marriages are becoming increasingly rare. It is more common that one becomes aware of a potential husband in everyday life, within the circle of family, friends and aquaintences, at Islamic events or by recommendation. Dating platforms especially for Muslim dating also are becoming increasingly important. ${ }^{71}$ Dates are always arranged in the presence of friends, one-on-one communication is only considerd to be in accordance to Islam via telephone or electronic media. Finally, the parents are called in and the first "official" meeting is arranged. Islamic rules regarding issues of matchmaking are mediated in lectures, materials and personal guidance within the MJD, but also by pop-Islamic youth culture, for example the youtube video "Finding the Girl". ${ }^{72}$

When it comes to marriage, the MJD encourages marriage contracts to regulate, for example, the employment of the wife, to specify the budget money and the duties of the husband assisting in housework, the potential number of children, the place of residence, the possibility of a polygamous marriage and everything else that is considered to be important, especially to strengthen the women's rights, for women are obliged to be obedient to their husband. Thus their rights should be negotiated before marriage.

So women's liberation is clearly limited by Islamic rules, which are considered to be a god-given path and framework of orientation that cannot be questioned. Obeying these rules is believed to be the most important duty and purpose in life, and individual needs and desires must be postponed to fulfill it. All at once Islam should be reactualized regarding the given context, so dicussions take place about issues of dowry, self-determined mate-choice, and marriage with non-Muslims, male dominance for example regarding inheritence or divorce law whilst considering female autarchy, polygyny and female circumcision. ${ }^{73}$ But it is emphasized that liberation has to be sought in and legitimized by Islamic sources and should never be product of assimilation to modern liberal values. ${ }^{74}$ Restricting options of action and the claim for obedience are downplayed, whilst being legitimized for protecting women as naturally in need of such protection. ${ }^{75}$ So the striving for self-control and individual sovereignty by Islamization is always

71 Cf. Internet sources: Muslimlife, partner search for muslims; ufuq-Newsletter, pp. $14 \mathrm{ff}$.

72 Cf. Internet sources: Finding the Girl.

73 Ramadan 2009, pp. 296 ff.

74 Muslim feminists like Amina Wadud or Fatima Mernissi are accused to suggest Bi'da.

75 Ali 2006, pp. xii-xxviii. 
challenged by patriarchal structures in Islamic ways of life and the given limits of interpretation. $^{76}$

\section{Firm in Faith. Muslim women as Agents of Islam}

Being a Muslim woman wearing the headscarf means bearing a lot of responsibility, one of the girls I got to know during the research process told me. This young woman had previously led a life she now views as dissolute, going out at night, having boyfriends, drinking and smoking, but now she had finally found her way back to Islam. By visiting the Islamic girl group associated with the MJD she began to increasingly align her lifestyle to Islamic rules. The wearing of the headscarf appears to be a major step in this direction, especially since she is aware that via this symbol she is publicly representing Islam. She therefore believes to bear the obligation and responsibility to be absolutely exemplary in her actions, not only to gain Allah's delight, but also to practice Da'wa, missionary work. ${ }^{77}$ The idea of Da'wa as an individual duty is propagated by lectures, nasihas (Islamic advice) in face-to-face-interactions and by the educational manual of the MJD: it explains that the women of the prophet distinguished themselves above all through the constant struggle on the path of Allah, through courage, commitment, perseverance and strength. ${ }^{78}$ Thus after the presentation of the life cycle of Asma it sums up:

This is the story of a hundred years of fighting and giving for Allah, the Blessed and Exalted. And you? How many years of your life are you willing to gift to Allah, the Blessed and Exalted? (...) Is it possible that among us women go out, take Asma bint Abi Bakr (ra) as an example and are willing to be successful in all areas of life ? ${ }^{79}$ (Translation V.M.)

Muslim women are respected for being strong, pious, devout and chaste, so the central message for the girls associated to the MJD is to adhere firmly to their creed, even if they have to make sacrifices. By this, they are encouraged to be really self-determined and free, because according to this worldview only Allah is able to grant peace and freedom.

We have the strength to do what we think is right

Even if it means putting up a life long fight

You see we are not controlled by a mini skirt and tight shirt

We are given only respect, and never treated like dirt

76 Nökel 2002, p. 49.

77 al-Bannā 1935; al-Faruqi 1986; Murad 1986; Wiedl 2008.

78 MJD-Manual.

79 MJD-Manual. 
So you see, we are the ones that are free and liberated

We are not the ones that are sexually terrorized and violated

We are the ones that are free and pure

We're free of STD's (sexual transmitted diseases) that have no cure

So when people ask you how you feel about the hood

Just sum up by saying, 'Baby it's all good'80

This mediated identity politics not only answers individual needs of orientation and social recognition, but also promotes a sociopolitical agenda, a politics of lifestyle striving for power of interpretation especially by propagating gender issuses. ${ }^{81}$ These are seen as evidence of moral sovereignty and are thus ensuring social recognition as avant-garde and elite. It is ascribed to Muslim women in this respect to serve as agents of Islamic identity politics, but likewise they gain orientation and social recognition. Because young Muslims associated with the MJD primarily seek belonging, recognition and orientation by and within an Islamic framework. They refuse to create individual religiosity and instead want to embrace true Islam, which is thought of as the universal and unchangeable truth. Given the fact that they are searching for belonging and recognition in the face of discrimination and Islamophobia, they conform themselves to social and religious expectations, which leads to a dynamic of becoming ever more orthodox in their Islamic lifestyles. Looking at inner-Islamic discourses, it has to be noticed that conservative groups gain interpretational sovereignty, while explicitly liberal positions $^{82}$ are mostly not noted at all. They are perceived as assimilation to postcolonial cultural hegemony, whilst the antinomies of modernity are brought into account to prove the superiority of true Islam. $^{83}$

To be a Muslim in this view means to practice Islam as a whole lifestyle, as an unnegotiable framework for all aspects of human Identity. A Muslim then is someone who puts himself completely into the service of Allah and will do his best to earn "points for paradise", because the threat of hell fire is ever-present. The service for Allah and his Ummah is seen as an individual task, which serves as criterion for being a good Muslim and ensures social recogition as well as an elite consciousness being part of a godly inspired and ultimatey triumphant avant-

80 MJD-Newsletter.

81 Flaig et. al. 1997; Giddens 1991.

82 Given the fact that Muslims who can be classified in this array aren't institutionalized at all and thus the access is rather difficult, there is a huge desideratum regarding their religiosity probably ranging from being explicitly non-religious, religiously indifferent, to being explicitly liberal or secular. They are rarely represented in research as well as in socio-political discourse, since they don't claim representation as Muslims. Moreover they often aren't recognized as true Muslims, because they don't fit into an orthodox and essential understanding of Islam.

83 Ramadan 2003; Van der Loo / van Reijen 1992. 
garde. This offers a contrast to experiences of social exclusion and discrimination which young Muslim women in Germany have to face in their everday lives. But it also demands individual submission - by choice - under what is believed to be the will of Allah, especially since it is believed to be accomplished only by sticking to the community of true believers, the Ummah. Thus the task to develop a perfect Islamic character in terms of a complete surrender to Allah's will is time and again experienced as an inner psychological pressure that might even yield depression, as I was told by some of those young Muslim women. They sometimes suffer from their self-imposed aspiration to be perfect, from the suppression of their needs in families and the discrimination of German society, especially in the workplace, as some of those young women told me. In Islamic contexts these young women are expected to meet these requirements, as is also apparent in the song "Dear Sister" by a German Muslim rapper called Ammar114, who is associated with the MJD, as he sings: "Never give up" ${ }^{84}$ Their "sacrifice" is interpreted as a positive steadfastness and provided with the aura of special dignity. This is also promoted by Native Deen's most popular song, an US-American hip hop Nasheed-band, which has also performed at MJD-Meetings: "Not afraid to stand alone" especially emphasizes the discrimination by non-Muslim society, as drawing attention to this reduces inner-Islamic critique by constructing a sense of belonging. ${ }^{85}$ Therefore they are considered to fill a special role, as discussed in a newsletter of the MJD as follows:

We consider our life here and now as the will of Allah and not as a coincidence. We get the daily opportunity to Da'wa. Isn't that a great Ni'ma (gift from Allah) to us Muslims? Doesn't it bring Baraka (blessings) for our lives? Is this not a task that Allah has imposed upon us here and now? (...) As long as we do not start to practice Islam step by step and with confidence, we will not be able to bring about a change in society and to overcome the problems in a timely manner. ${ }^{86}$ (Translation V.M.)

Thus it is believed that Islam is the right solution for issues perceived as problems of contemporary societies: broken homes, free sexuality, drug abuse, ecological crisis, economic exploitation and injustice. Therefore the MJD considers it their task to declare the supremacy of Islam as an overall lifestyle to young Muslims to fight tendencies of un-Islamic liberations or growing secularism, which in this view leads to delinquency, individual distress and social chaos (fitna). It also struggles against traditional understandings of Islam and against jihadism, for Da'wa has to be non-violent. This positioning is mediated by a song by

84 Cf. Internet sources: Ammar114 - Liebe Schwestern; Herding 2013, pp. 84 ff.

85 Cf. Internet sources: Native Deen - Not afraid to stand alone.

86 MJD-Newsletter. 
Ammar114, referring to juvenile delinquency, honour killing and Muslim terror as misunderstanding of Islamic sources. ${ }^{87}$

It is very unapparent at first glance that the MJD stands for a rather political interpretation of Islam, since Islamic sources are considered to be the guideline for all aspects of human life, which also claims collective social and political impacts. The understanding of Islam the MJD conveys is oriented particularly deeply to the writings of Tariq Ramadan, son of the Muslim Brother Said Ramadan and grandson of the founder of the Egypt Muslim Brotherhood, Hassan alBanna. The central theme of his works, which also were published by the MJD, is a European-Islamic identity. It is characterized by participation and success in the society Muslims live in, while also strictly maintaining Islamic values and conducting life practice.

Migration is seen as providence to bear witness to Allahs truth and to invite everyone to it. Tariq Ramadan states that being a true Muslim means making a contribution to society through volunteering activities, political engagement and successful professional work interpreted as the duty of Da'wa. Referring to this, the MJD emphasizes the task to further society as a Muslim, to establish an Islamic social order, for Islam is considered to deliever a universal truth that is viable at all times and in all spaces. ${ }^{88}$ Ramadan sees himself as a "Reformist Salafi" because he prompts the individual as well as society to an uncompromising focus on and orientation to Islamic sources and at the same time rejects traditions (taqlid) as well as literalist understandings while postulating a contextual interpretation of Islamic sources in the sense of Ijtihad. ${ }^{89}$ To find true Islam, its universal core, Ramadan thinks it has to be cleansed of cultural influences and innovations (Bi'da) to adopt contemporary contextual forms customizably, but likewise sticking to Islamic principals without any compromise. In this regard Ramadan also demands a critical and rational reinterpretation of Islamic sources regarding patriarchy especially negotiating issues of education and self-determination of women, for example autarchy, choice of future husband, contraception and abortion. All at once he insists on not being afraid to defy social conventions. Ramadan ties the process of Islamic reawakening to the effort of Muslim women. In his view women's liberation has to stick to the essence of feminity according to Islam and must not assimilate to the Western women's emancipation movement. ${ }^{90}$ While some classify Ramadan as a modern Islamic thinker who explicitly situates democracy and women's rights within Islam, others see him as a wolf in sheep's clothing who strives for the Islamization of Europe, as he emphasizes the affirmation of faith (shahada) and the duty of Da'wa to es-

87 Cf. Internet sources: Ammar114 - Fünf32.

88 Ramadan 2003.

89 Cf. Internet sources: "Salafismus" - Tariq Ramadan 1/4 - IGD-Jahrestreffen 2012.

90 Ramadan 2009, p. 289. 
tablish an Islamic social order, which exceeds individual religiosity by a social conservative agenda. ${ }^{91}$

\section{Conclusion}

Previous studies have pointed out the changing religiosity of young Muslims in Germany to be a process of individualization, which is admittedly considered to be a main factor of religious transformation in contemporary Islam. ${ }^{92}$ But my observation revealed that individualization is rebound to, and limited by, processes of communitization. Community buildung decisively affects issues of gender order and gender roles. Notwithstanding Islamization of lifestyle is a product of secularization and individualization, it also sets - as a backlash - clear boundaries to these processes.

So on the one hand transformations of Islam as observed within the field of the MJD must be interpreted as a process of individualization: The emphasis on the Muslim subject, on individual choice required to be a true Muslim ${ }^{93}$ and the plausibility of interpretative schemes, that have to be experienced, the struggle with other world views as well as with different understandings of Islam and the contemporary forms of mediation of the propagated worldview by huge events, media and youth culture are indicators and results of processes of individualization. Within this perspective the MJD provides opportunities to acquire a social position which allows to resist claims of assimilation by society and the parental generation and provides agency beyond those dichotomous aspirations. ${ }^{94}$ The return to Islam and a gender order in accordance to it, can both be seen as resistance against Western domination, processes of social exclusion and stigmatization, but also against traditional Islam transmitted by the parental generation, as Muslim women themselves emphasize.

On the other hand these processes are limited by normative discourses on issues of idealized community building, whilst sociocultural distinctions are constructed and marked by a specific gender order and mediated through artefacts of Islamic youth culture. So the Islamization of the self goes along with a specific habitualization of doing religion and doing gender. ${ }^{95}$ In this regard it is ascribed to Muslim women to play an important role building up a strong, firm and proud Ummah, which through this is - more or less - immunized against selfcritique. In this regard, rationalization of Islamic knowledge is limited because, within the scene of the MJD, it is not required to scrutinize basic creeds. Muslim

91 Ghadban 2006; Remien 2007; Zu Fürstenberg 2008; Fourest 2008.

92 Klinkhammer 2000; Tietze 2001; Frese 2002; Nökel 2002.

93 Klinkhammer 2000; Klein-Hessling / Werner / Nökel (eds.) 1999.

94 Mahmood 2005; cf. Internet sources: Korteweg 2008.

95 Nökel 2002, p. 61. 
women are rather conventionalized as Islamic activists fulfilling their duty of Da'wa and thus manufacturing a new Islamic generation. Bodies and identites of women thus become the venue of struggles for interpretational sovereignty between Islamophobia on the one hand and apologetic counter-discourses claiming an essential, true Islam on the other. ${ }^{96}$ Although referring to Western concepts of emancipation and self-determination, Muslim women clearly distinguish themselves from these self-conceptions and meanings, which are accused of being decadent, wicked and based on double-standards. With regard to these stereotypes Muslim women in the MJD are summoned to fight against everything unIslamic by completely Islamizing their lifestyles. The antagonsim between Islam and everything which is un-Islamic is socially constructed but nevertheless powerful as a given social reality, if the individual submits to this world view. It is based on the distinction between halal (permitted) and haram (prohibited), whilst categories in between are mostly blanked out. ${ }^{97}$

The mediated gender order is situated between the poles of emancipation and a reifying of traditional gender order by naturalizing it. This identity politics must be analyzed as a reaction to social transformations of gender roles as well as religiosity resulting in processes of modernization ${ }^{98}$, which are perceived as colonial hegemony. The intersection of gender, religion and race is the contextual background that can highlight the motives to adopt this gendered identity politics: Islamization of the self means adopting an Islamic gender role and according to self-concepts, must be understood as affirmative action as a minority. ${ }^{99}$ Lines of difference between Islamic and Western gender orders are also interrelated to those between religious and non-religious. It also is a reaction against processes of secularization within the migrant community. So doing Islam goes along with doing gender, as Islamic identity politics is mingled with gender politics. ${ }^{100} \mathrm{Re}$ versely the construction of Islamic feminity bothers young Muslim women, for being an authentically Muslim woman you have to perform Islam as a gendered action: ${ }^{101}$ Via discipline and self-control they distinguish themselves against their uneducated parents to gain social recognition..$^{102}$

Muslim women have to handle such breaches regarding their self-ascriptions as being emancipates and self-determines by themselves, for within the Islamic view they are overlooked or construed as indespensible sacrifices: Processes of discrimination, especially against women wearing headcarves who can hardly find a job, as well as discrimination by the given Islamic gender order propagating

96 Von Braun / Mathes 2007.

97 Ali 2007.

98 Van der Loom / van Reijen 1997.

99 Stauth 2000, p. 14; Nökel 2002.

100 Wohlrab-Sahr 1999, pp. 143-223.

101 Nökel 2002, p. 59.

102 Nökel 2002, pp. 68 ff ; also Bourdieu 1982.

\section{8}


obedience under Islamic rules regarding love, sexuality and partnership are just considerd to be benefits on the way to paradise.

As young Muslim women in the MJD seek belonging within a like-minded community, the offer of communitization is perceived as attractive. However, they have to submit to the needs of the Islamic community. So the Umma as an idealized utopia of solidarity and justice and as experience-oriented youth-culture of like-minded persons, as well as the omnipresent call to build up a strong, firm and consistent community is central for the propagated understanding of Islam within the MJD. This emphasis on community building based on a specific notion of German Muslim identity and expressed by a Muslim lifestyle, challenges and also limits processes of indvidualization and individual understandings of Islamic sources and traditions. As an ideology of community building, the Islamic society is considered to be the best one, according to its purpose to "commanding what is just and forbid what is evil" (3:110). By competing for good deeds to attain Allah's delight, true Muslims are - in this view - forced to establish an all-embracing, moral-based and god-given order of life, which also implies a specific gender order.

The Umma is constructed by processes of othering as a community of a discriminated minority and the inversion as idealized elite chosen by Allah, which can be seen as an apologetic counter-discourse. Constructions of identity and identity politics are embedded in relative structures of power and hegemony, which have to be analyzed critically. Not only mainstream society deploys power relations, they are also effective within the Islamic field, as was shown by analyzing the social and religious positioning represented by the gendered idenitypolitics of the MJD. Thus, Muslim women are embedded in power structures and all at once contribute to retain them, constructing religious and gendered power relations, which have to be analyzed concerning their social impact. ${ }^{103}$

On a final note I want to emphasize the importance of what Birgit Heller and Morny Joy claimed to be an inevitable ethical impetus of a gender critical approach: Analyzing transformations of religion and gender in their intermingling within the given context has to critically reflect relative power structures and subtle differences without being ideologically coopted or religiously bound. ${ }^{104}$ Against this backdrop, I have to conclude that analyzing my data only within the paradigm of individualization would mistakenly suggest a trend of increasing liberalism, ignoring power structures within the Islamic field and thus implicitly reinforcing them. Of course one can observe steps in the direction of liberation and agency within the field, and it is important to expose that; but these steps are limited especially regarding gender issues, as the critical analysis of self-descriptions of Muslim women shows. Social exclusions and depreciations implied with

103 Referring to the interplay of constraint and self-constraint: Elias 1976 [1939]; Foucault 1978.

104 Heller 2010, pp. 137-147; Joy 2001, pp. 177-195. 
this Islamic gender politics regarding all lifestyles perceived as un-Islamic (hedonistic, liberal, secular lifestyles as well as homosexual identities) are prevalent and effective, they reveal inner-Islamic power structures at stake, that must be critically analyzed. This has to be done without inspiring Islamo- and xenophobic discourses, which are increasing in Germany and across Europe. Overlooking inner-Islamic cleavages by concentrating on power-relations between a German majority and an Islamic minority implicitly feeds an essential and conservative understanding of Islam, which claims representation as true Islam and is publicy visible as such. Thus gendered Islamic identity constructions of young Muslim women must be assessed within the context of inner-Islamic discourses as well as within wider society to both reconstruct and deconstruct them to earn a hardwon ethical impetus beyond a dichotomous judgment.

\begin{tabular}{|l|l|l|l|}
\hline $\begin{array}{l}\text { Interview } \\
\text { Number }\end{array}$ & Gender & Date & Place \\
\hline Nr. 1 & weiblich & 8.4 .2014 & Hannover, At her home \\
\hline Nr. 2 & weiblich & 5.4 .2014 & $\begin{array}{l}\text { Hannover, In the Mosque and then at her aunts } \\
\text { home }\end{array}$ \\
\hline Nr. 3 & weiblich & 28.4 .2014 & Hannover, In a park \\
\hline Nr. 4 & weiblich & 5.11 .2011 & $\begin{array}{l}\text { Rüsselsheim, Othman-Ibn-Affan-Mosque, At } \\
\text { the members meeting }\end{array}$ \\
\hline Nr. 5 & weiblich & 7.8 .2010 & German Youth-Hostel, MJD-Summer-School \\
\hline Nr. 6 & weiblich & 6.8 .2010 & German Youth-Hostel, MJD-Summer-School \\
\hline Nr. 7 & weiblich & 7.8 .2010 & German Youth-Hostel, MJD-Summer-School \\
\hline Nr. 8 & männlich & 7.8 .2010 & German Youth-Hostel, MJD-Summer-School \\
\hline Nr. 9 & männlich & 5.11 .2011 & $\begin{array}{l}\text { Rüsselsheim, Othman-Ibn-Affan-Mosque, At } \\
\text { the members meeting }\end{array}$ \\
\hline
\end{tabular}

Table 1: Overview qualitative interviews

\section{References}

Abed, Sandra: Noura. Berlin 2011.

Al-Bannā, Hasan: Dawatu-nā ("Unsere Dawa"). Kairo 1935.

Al-Faruqi, Ismail: The path of Dawah in the West. London 1986.

Al-Harmaneh, Ala / Thielmann, Jörn (eds.): Islam and Muslims in Germany. Leiden / Boston 2008.

Ali, Kecia: Sexual Ethics and Islam. Feminist Reflections on Qur'an, Hadith and Jurisprudence. Oxford 2006. 
Alpsoy, Said: Der Prophet als Mensch. Berlin 2007.

Amir-Moazami, Shirin: Politisierte Religion: Der Kopftuchstreit in Deutschland und Frankreich. Bielefeld 2007.

Bano, Masooda / Kalmbach, Hilary (eds.): Women, Leadership and Mosques. Changes in Contemporary Islamic Authority. Leiden / Boston 2012.

Barot, Rohit: Religion and ethnicity: Minority and social change in the metropolis. Kampen 1993.

Barth, Fredrik: Ethnic groups and boundaries: The social organization of cultural difference. Boston 1969.

Bayerisches Staatsministerium des Innern, für Bau und Verkehr (ed.): Verfassungsschutzbericht 2010-2015.

Beck, Ulrich / Beck-Gernsheim, Elisabeth: Riskante Freiheiten. Individualisierung in modernen Gesellschaften. Frankfurt am Main 1998.

Bendixen, Synnove: The religious identity of young muslim women in Berlin: an ethnographic study. Leiden 2013.

Bourdieu, Pierre: Die feinen Unterschiede. Kritik der gesellschaftlichen Urteilskraft. Frankfurt am Main 1982.

Braun, Christina von / Mathes, Bettina: Verschleierte Wirklichkeit: die Frau, der Islam und der Westen. Berlin 2007.

Breuer, Rita: Zwischen Ramadan und Reeperbahn: Die schwierige Gradwanderung der muslimischen Minderheit. Freiburg im Breisgau et. al. 2006.

Bundesministerium des Inneren (ed.): Verfassungsschutzbericht 2010.

Cavuldak, Ahmet: Jugendszenen in Deutschland - zwischen Islam und Islamismus (= Analysen \& Argumente 97). Berlin 2011.

Ceylan, Rauf / Kiefer, Michael (eds.): Fundamentalistische Strömungen und Radikalisierungsprävention. Wiesbaden 2013.

Crenshaw, Kimberlé: "Mapping the Margins: Intersectionality, Identity Politics, and Violence against Women of Color", in: Stanford Law Review (43/6) 1991, pp. 12411299.

Degele, Nina / Winker, Gabriele: Intersektionalität. Zur Analyse sozialer Ungleichheiten. Bielefeld 2009.

Demiryürek, Mustafa: Jung \& Muslim. Berlin 2007.

Elias, Norbert: Über den Prozeß der Zivilisation. Soziogenetische und psychogenetische Untersuchungen. Frankfurt am Main 1976 [1939].

Fend, Helmut: Entwicklungspsychologie des Jugendalters. Wiesbaden 2003.

Flaig, Bodo et. al.: Alltagsästhetik und politische Kultur. Zur ästhetischen Dimension politischer Bildung und politischer Kommunikation. Bonn 1997.

Foucault, Michel: Dispositive der Macht. Michel Foucault über Sexualität, Wissen und Wahrheit. Berlin 1978.

Fourest, Caroline: Brother Tariq: The Doublespeak of Tariq Ramadan. London 2008. Franke, Edith / Maske, Verena: "Teilnehmende Beobachtung als Verfahren qualitativer Religionsforschung”, in: Lehmann, Karsten / Kurth, Stefan (eds.): Religionen erforschen. Kulturwissenschaftliche Methoden in der Religionswissenschaft. Wiesbaden 2011.

Franke, Edith / Maske, Verena: "Religionen, Religionswissenschaft und die Kategorie Gender. Zur Notwendigkeit einer geschlechterdifferenzierenden Forschung in der 
Religionswissenschaft", in: Stausberg, Michael (ed.): Studienbuch Religionswissenschaft. Berlin / Boston 2012, pp. 125-140.

Frese, Hans-Ludwig: Den Islam ausleben. Konzepte authentischer Lebensführung junger türkischer Muslime in der Diaspora. Bielefeld 2002.

Fürstenberg, Nina zu: Wer hat Angst vor Tariq Ramadan? Der Mann, der den Islam reformieren und die westliche Welt verändern will. Freiburg im Breisgau 2008.

Gerlach, Julia: Zwischen Pop und Dschihad: Muslimische Jugendliche in Deutschland. Berlin 2013.

Ghadban, Ralph: Tariq Ramadan und die Islamisierung Europas. Berlin 2006.

Giddens, Anthony: Modernity and Self-Identity. Self \& Society in the Late Modern Age. Cambridge 1991.

Goffman, Erving: Stigma: Über Techniken der Bewältigung beschädigter Identität. Frankfurt am Main 2014 (Orig. Stigma: Notes on the management of spoiled identity, 1963).

Haddad, Yvonne Yazbeck / Smith, Jane I. (eds.): Muslim Minorities in the West. Visible and Invisible. Boston 2002.

Havighurst, Robert J.: Human development and education. New York 1953.

Heller, Birgit: "Dekonstruktion von Objektivität, Wertfreiheit und kritischer Distanz: Impulse der Frauenforschung/Gender Studies für die Religionswissenschaft", in: Lanwerd, Susanne / Moser, Márcia (eds.): Frau-Gender-Queer. Gendertheoretische Ansätze in der Religionswissenschaft. Würzburg 2010, pp. 137-147.

Herding, Maruta: Inventing the Muslim Cool: Islamic Youth Culture in Western Europe. Bielefeld 2013.

Hessisches Ministerium des Inneren und für Sport (ed.): Verfassungsschutz in Hessen. Bericht 2010; 2011.

Honneth, Axel: Kampf um Anerkennung: Zur moralischen Grammatik sozialer Konflikte. Frankfurt am Main 1998.

Hunner-Kreisel, Christine / Andresen, Sabine (eds.): Kindheit und Jugend in muslimischen Lebenswelten: Aufwachsen und Bildung in deutscher und internationaler Perspektive. Wiesbaden 2010.

Hurrelmann, Klaus: Lebensphase Jugend. Eine Einführung in die sozialwissenschaftliche Jugendforschung. Weinheim et. al. 2007.

Innenministerium Baden-Württemberg (ed.): Verfassungsschutzbericht Baden-Württemberg 2005, 2006, 2007, 2013.

Jenkins, Richard: Social Identity. London 2008.

Jonker, Gerdien / Amiraux, Valérie: Politics of Visibility. Young Muslims in European Public Spaces. Bielefeld 2006.

Joy, Morny: "Postcolonial Reflections: Challenges of Religious Studies", in: MTSR (13) 2001, pp. 177-195.

Karam, Azza: Women, Islamism, and the State. New York 1998.

Kepel, Gilles: Allah im Westen. Die Demokratie und die islamische Herausforderung. Übers. Inge Leipold. München 1996.

Klein-Hessling, Ruth / Werner, Karin / Nökel, Sigrid (eds.): Der neue Islam der Frauen: Weibliche Lebenspraxis in der globalisierten Moderne. Fallstudien aus Afrika, Asien und Europa. Bielefeld 1999. 
IMAN-cipation - Identity Politics of young Muslim Women

Klinkhammer, Gritt: Moderne Formen islamischer Lebensführung. Eine qualitatiiv-empirische Untersuchung zur Religiosität sunnitisch geprägter Türkinnen der zweiten Generation in Deutschland. Marburg 2000.

Lemmen, Thomas: Islamische Organisationen in Deutschland. Bonn 2000.

Lübcke, Claudia / von Wensierski, Hans-Jürgen (eds.): Junge Muslime in Deutschland. Lebenslagen, Aufwachsprozesse und Jugendkulturen. Opladen 2007.

Lüddeckens, Dorothea / Uehlinger, Christoph / Walthert, Rafael: Die Sichtbarkeit religiöser Identität: Repräsentation - Differenz - Konflikt. Zürich 2013.

Mahmood, Saba: The Politics of Piety: The Islamic Revival and the Feminist Subject. Princeton 2005.

Mansour, Ahmad: Generation Allah: Warum wir im Kampf gegen religiösen Extremismus umdenken müssen. Frankfurt am Main 2015.

Maréchal, Brigitte: The Muslim Brothers in Europe: Roots and discourse. Boston / Leiden 2008.

Maske, Verena: "Die Muslimische Jugend in Deutschland e.V. (MJD)", in: Tworuschka, Udo / Klöcker, Michael (eds.): Handbuch der Religionen, Kirchen und andere Glaubensgemeinschaften in Deutschland im deutschsprachigen Raum (HdR). 26. Ergänzungslieferung. Landsberg 2010a, IV - 3.12.1-3.12.24.

Maske, Verena: "Islamisch und trendbewusst. Zum Verhältnis von Kleidungsstil, Geschlechtskonstruktion und religiöser Identität bei jungen Musliminnen in Deutschland", in: Hartlieb, Elisabeth / Koslowski, Jutta / Wagner-Rau, Ulrike (eds.): Das neue Kleid. Feministisch-theologische Perspektiven auf geistliche und weltliche Gewänder. Sulzbach am Taunus 2010b, pp. 235-260.

Maske, Verena: "Junge Musliminnen in Deutschland zwischen Integration und Abgrenzung”, in: Lewicki, Alexandra / Möller, Melanie / Richter, Jonas / Röscher, Henriette (eds.): Religiöse Gegenwartskultur: Zwischen Integration und Abgrenzung. Münster et. al. 2010c.

Maske, Verena: "Gottesfürchtig auf Erfolgskurs. Der Pop-Islam, eine muslimische Jugendkultur in Deutschland", in: Franke, Edith / Runge, Konstanze (eds.): Von Derwisch-Mütze bis Mekka-Cola. Vielfalt islamischer Glaubenspraxis. Begleitband zur Sonderausstellung der Religionskundlichen Sammlung der Philipps-Universität Marburg, Bd. 6. Marburg 2013, pp. 87-107.

Meining, Stefan: Eine Moschee in Deutschland: Nazis, Geheimdienste und der Aufstieg des politischen Islam im Westen. München 2011.

Mitchell, Richard Paul: The society of the Muslim Brothers. New York et. al. 1993.

Murad, Khurram: Da'wah among Non-Muslims in the West: Some Conceptual and Methodological Approach. Leicester 1986.

Nökel, Sigrid: Die Töchter der Gastarbeiter und der Islam: Zur Soziologie alltagsweltlicher Anerkennungspolitiken. Eine Fallstudie. Bielefeld 2002.

Rabasa, Angel M.: The Muslim World after 9/11. Santa Monica, C.A. et. al. 2004.

Ramadan, Tariq: Die Muslime im Westen. Aufbauen und Mitgestalten. Berlin 2003.

Ramadan, Tariq: Radikale Reform. Die Botschaft des Islam für die moderne Gesellschaft. München 2009.

Remien, Florian: Muslime in Europa: Westlicher Staat und islamische Identität. Untersuchung zu Ansätzen von Yusuf al-Qaradawi, Tariq Ramadan und Charles Taylor (= Bonner Islamwissenschaftliche Hefte 3). Schenefeld, Hamburg 2007. 
Riegel, Christine / Geisen, Thomas: Jugend, Zugehörigkeit und Migration: Subjektpositionierung im Kontext von Jugendkultur, Ethnizitäts- und Geschlechterkonstruktionen. Wiesbaden 2007.

Roy, Olivier: Der islamische Weg nach Westen: Globalisierung, Entwurzelung und Radikalisierung. München 2006.

Schiffauer, Werner: Migration und kulturelle Differenz. Studie für das Büro der Ausländerbeauftragten des Senats von Berlin. Berlin 2002.

Schneiders, Thorsten Gerald: Salafismus in Deutschland: Ursprünge und Gefahren einer fundamentalistischen Bewegung. Bielefeld 2014.

Spielhaus, Riem: Wer ist hier Muslim? Die Entwicklung eines islamischen Bewusstseins in Deutschland zwischen Selbstidentifikation und Fremdzuschreibung. Würzburg 2011.

Stauth, Georg: Islamische Kultur und moderne Gesellschaft. Bielefeld 2000.

Tarlo, Emma / Moers, Annelies (eds.): Islamic fashion and anti-fashion: New Perspectives from Europe and North America. London / New York 2013.

Tiesler, Nina Clara: Muslime in Europa: Religion und Identitätspolitiken unter veränderten gesellschaftlichen Verhältnissen. Berlin 2006.

Tietze, Nikola: Islamische Identitäten. Formen muslimischer Religiosität junger Männer in Deutschland und Frankreich. Hamburg 2001.

Van der Loo, Hans / van Reijen, Willem: Modernisierung: Projekt und Paradox. München 1992.

Vertovec, Steven / Peach, Ceri (eds.): Islam in Europe: The Politics of Religion and Community. Basingstoke 1997.

Weber, Max: Die protestantische Ethik und der Geist des Kapitalismus. Tübingen 2016 [1905].

Wensierski, Hans-Jürgen von: "Die islamisch-selektive Modernisierung - Zur Struktur der Jugendphase junger Muslime in Deutschland", in: Lübcke, Claudia / Wensierski, Hans-Jürgen (eds.): Junge Muslime in Deutschland. Lebenslagen, Aufwachsprozesse und Jugendkulturen. Opladen 2007.

Whitehead, Stephen / Talahite, Anissa / Moodley, Roy: Gender and Identity. Key Themes and new Directions. Don Mills, Ontario 2013.

Wiedl, Nina: Dawa - Der Ruf zum Islam in Europa. Berlin 2008.

Wohlrab-Sahr, Monika: Konversionen zum Islam in Deutschland und den USA. Frankfurt am Main / New York 1999.

\section{Internet sources}

Ammar114 - Fünf32 (Jugendkriminalität, Ehrenmord, Terror), Youtube-video, upload 24.04.2008, available at: https://www.youtube.com/watch?v=ID-U_xjbKd8 [07.10.16]. Ammar114 - Liebe Schwestern, Youtube-video, upload 04.11.2016, available at: https:// www.youtube.com/watch?v=1nmHYCZ2M94 [07.10.16].

anonymous3188897430: Hand in Hand gegen Zwangsheirat, 22.04.2008, available at: http://tariqramadan.com/english/hand-in-hand-gegen-zwangsheirat/ [31.01.2017].

Dantschke, Claudia: Die muslimische Jugendszene, 05.07.2007, available at: http://www. bpb.de/politik/extremismus/islamismus/36402/jugendorganisationen [07.10.16]. 
IMAN-cipation - Identity Politics of young Muslim Women

Der Prophet als Ehemann, available at: http://www.islamicbulletin.org/german/ebooks/ mohammed/de_der_prophet_als_ehemann.pdf [07.10.16].

Dernbach, Andrea: "Muslime rücken langsam aus dem Fokus", in: Tagesspiegel, 12.07.2015, available at: http://www.tagesspiegel.de/politik/verfassungsschutz-mus lime-ruecken-langsam-aus-dem-fokus/12043960.html [07.10.16].

FEMYSO (Forum of European Muslim Youth and Student Organisations), website, available at: http://www.femyso.org/home [31.01.2017].

Finding the Girl. A Homemade Islamic cartoon about a young Muslim man's search for a spouse: https://www.youtube.com/watch?v=GJxpKM03q_I [07.10.16].

Hima - Natur- und Umweltschutz aus islamischer Perspektive, blog, available at: http:// hima-umweltschutz.blogspot.de/p/islam-und-unweltschutz.html [07.10.16].

i,Slam: Khalid Bounouar - Mutter, Youtube-video, upload 21.11.2013, available at: https://www.youtube.com/watch? $\mathrm{v}=\mathrm{dVyOapdA} 4 \mathrm{x} 4$ [07.10.16].

i,Slam, website, available at: http://www.i-slam.de/index.php/de/ [07.10.16].

Islamic Relief Deutschland, website, available at: http://islamicrelief.de [07.10.16].

Kiefer, Michael: Lebenswelten muslimischer Jugendlicher - eine Typologie von Identitätsentwürfen, 2009, available at: http://www.kiefer-michael.de/mediapool/10/108594/ data/Lebenswelten_muslimischer_Jugendlicher.pdf [07.10.16].

Korteweg, Anna C.: "The Sharia Debate in Ontario: Gender, Islam, and Representations of Muslim Women's Agency”, in: Gender \& Society (22) 2008, available at: https:// korteweg.files.wordpress.com/2010/12/korteweg-2008-gender-society-sharia-debate. pdf [10.01.2017].

Maher Zain - For the rest of my life, Youtube-video, upload 27.09.2011, available at: https://www.youtube.com/watch?v=PHbZ9SXHJwA [07.10.16].

MJD meeting 2012, invitation on facebook, available at: https:/www.facebook.com/Wir. Gewinnt/photos/a.289605204392092.75887.289604071058872/370399482979330/?type $=1 \&$ theater [07.10.16].

Muslimische Jugend in Deutschland e. V. (MJD), website, available at: http://www.mjdnet.de/die-mjd [07.10.16].

Muslimas mit Mumm!, poster, available at: https://laylahijabblog.files.wordpress.com/ 2010/03/muslimasmitmumm-iceimg_assist_custom.jpg [31.01.2017].

Muslimlife, partner search for muslims, available at: https://www.muslimlife.eu [07.10.16].

My Mum is Amazing - Allah Knows by Zain Bhikha, Youtube-video, upload 16.09.2007, available at: https://www.youtube.com/watch $? \mathrm{v}=0 \mathrm{OKndnaiFzo \& index}=5 \&$ list $=\mathrm{RD}$ 2ZdHfVF5Zfg [07.10.16].

Narrabila-Verlag, website, available at: https://www.narrabila-verlag.de [07.10.16].

Native Deen - Not afraid to stand alone, Youtube-video, upload 15.09.2007, available at: https://www.youtube.com/watch?v=wAfUMfCtcDA [07.10.16].

Nayzak: "gender equity in Islam", poster, on: DeviantArt, available at: http://nayzak. deviantart.com/art/gender-equity-in-Islam-306859757 [31.01.2017].

Orde, Sabine am: "Das Wichtigste ist die Liebe" - Kampf gegen muslimische Zwangsheiraten, 17.07.2008, in: taz.de, verfügbar unter: http://www.taz.de/!5178861/ [07.10.16].

Rasoulallah.net Versionen: Der Prophet als Ehemann, availalbe at: http://www.islamicinvitation.com/downloads/prophet-pbuh-as-husband_ger.pdf [07.10.16]. 
"Salafismus" - Tariq Ramadan 1/4 - IGD-Jahrestreffen 2012, Youtube-video, upload 23.06.2012, available at: https://www.youtube.com/watch?v=fsZPWSG7fqI [07.10.16].

Sami Yusuf - Mother, Youtube-video, upload 26.05.2009, available at: https://www. youtube.com/watch?v=dUC2WptPwT0 [07.10.16].

Styleislam (Label für Lifestyle-Produkte und Casualwear), online shop, available at: http://www.styleislam.eu [07.10.16].

The Sound of Reason - Mom Song, Youtube-video, upload 10.05.2012, available at: https://www.youtube.com/watch?v=z7r4JzcAxTc [07.10.16].

This is not hijab, blog, available at: https://islamgreatreligion.wordpress.com/tag/this-isnot-hijab/ [7.10.16].

Ufuq-Newsletter - Jugendkultur und politische Bildung in der Einwanderungsgesellschaft: Jugendkultur, Religion und Demokratie - Politische Bildung mit jungen Muslimen (ufuq-Newsletter 6/Juni 2008), available at: http://ufuq.de/pdf/ Newsletter\%206-2008.pdf [31.01.2017].

Ummah 2.0, poster, available at: http://www.muslimische-jugend.de/zeit/winter-2010 [07.10.16].

Women I love - Zain Bhikha - Official video 2011, Youtube-video, upload 09.11.2011, available at: https://www.youtube.com/watch?v=ZWKZqMvdNJU [31.01.2017].

“Wir gewinnt!" - Video Jahresmeeting MJD 2012, available at: https://www.youtube. com/watch $? \mathrm{v}=$ XAnUaPMN8kw [07.05.2017].

World Assembly of Muslim Youth (WAMY), website, available at: http://www.wamy.org [07.10.16].

Zaki: "Jannah under mothers feet Facebook Wallpaper", poster, on: DeviantArt, available at: http://zaki994.deviantart.com/art/Jannah-under-mothers-feet-FacebookWallpaper-303923456 [31.01.2017].

Verena Maske, M.A., Institut für Vergleichende Kulturforschung, Fachgebiet Religionswissenschaft, Philipps-Universität Marburg, Landgraf-Philipp-Str. 4, 35032 Marburg, Germany, maske@staff.uni-marburg.de

Citation: Maske, Verena: "IMAN-cipation - Identity Politics of young Muslim Women within the 'Muslim Youth in Germany e.V. (MJD)' between Agency, Submission and Repression. An Analysis of the Transformation of Gender-Roles", in: Heller, Birgit (ed.): Religion, Transformation and Gender. (J-RaT 2017 / 2), pp. 125-156.

Datum der Publikation: 02.10.2017 